\title{
The Four Kingdom Schema and the Seventy Weeks in the Arabic Reception of Daniel
}

\author{
Miriam L. Hjälm
}

Throughout the ages, Jews, Christians, and Muslims have used the periodization motifs in the book of Daniel to interpret past, present and future events and to understand their own place within sacred history. For most Christian commentators in patristic times, the four different materials representing four successive kingdoms, which comprised the statue in Daniel 2, were identified as Babylonia, Media-Persia, Greece, and Rome. ${ }^{1}$ The stone that grew into a mountain and shattered all previous kingdoms was identified as Christ and his kingdom, the eternal Church. Further east, the flexibility of the four kingdoms motif was put to the test when the people of the book ${ }^{2}$ were subjected by yet another empire, one none of the patristic interpreters had imagined. In the wake of the Arab victories over Byzantium, the interpretation of the kingdoms was thus often adapted. ${ }^{3}$ In the Syriac Apocalypse of Pseudo-Methodius the interpretation of the final kingdom was expanded to include the Greek, the Roman, and the Byzantine empires with a reference to the Kushites. This final kingdom waged war with Islam and defeated it. ${ }^{4}$ In another Syriac tract, the four kingdoms were identified with Rome, Persia, Media, and finally the

* The present article was composed with support from the Swedish Research Council (2017o163o). My gratitude to Yonatan Moss for commenting on the draft version of this paper.

1 For the dominance of this interpretation as well as minority views, see Pier Franco Beatrice, "Pagans and Christians on the Book of Daniel," StPatr 25 (1991): 27-45; Brennan W. Breed, "History of Reception," in Daniel: A Commentary, by Carol A. Newsom with Brennan W. Breed, отL (Louisville: Westminster John Knox, 2014), 85-97, 243-52, 309-20, here 85. See also the discussion on Daniel 7 below.

2 The term is used for Jews and Christians in the Qurān, including suras 29:46 and 3:113.

3 See for instance Wido van Peursen, "Daniel's Four Kingdoms in the Syriac Tradition," in Tradition and Innovation in Biblical Interpretation: Studies Presented to Professor Eep Talstra on the Occasion of his Sixty-Fifth Birthday, ed. W. Th. van Peursen and J. W. Dyk, ssN 57 (Leiden: Brill, 2011), 189-207.

4 See Michael Philip Penn, When Christians First Met Muslims: A Sourcebook of the Earliest Syriac Writings on Islam (Oakland: University of California Press, 2015), 108-29. For studies and related narratives, see also Lutz Greisiger, "The Apocalypse of Pseudo-Methodius [Syriac]," in Christian-Muslim Relations: A Bibliographical History, vol. 1: 6oo-9oo, ed. D. Thomas and B. Roggema (Leiden: Brill, 2009), 1:163-71. 
Muslim empire. ${ }^{5}$ In a Coptic-Arabic recension of Daniel, the source text itself was expanded by the addition of a chapter in which Islamic rulers are included in the schema-a topic to which we will return.

Still awaiting their messiah, Jews typically identified the stone "cut without hands" with the messianic kingdom as well and their interpretations of the four kingdoms were just as flexible as those of their Christian peers. The prolific Jewish Rabbanite scholar Saadiah Gaon (d. 942 CE) and his near contemporary, the Karaite intellectual Yefet ben Eli, both reinterpreted the model by subsuming the Muslim caliphate under the Roman-Byzantine Christian empire to represent the fourth kingdom: the iron in Dan 2:40-43 is identified with Rome/Byzantine and the clay with the Arabs-according to Yefet a bifurcation supported by the words "the [fourth] kingdom shall be divided." Yet a different solution was offered by Ibn Ezra (d. $1167 \mathrm{CE}$ ) who merged the chronologically more distant Greeks and Romans/Byzantines into a third empire which allowed him to interpret the fourth kingdom as the Muslim empire. ${ }^{6}$

Though the book of Daniel is only rarely—if at all-referenced in the Qurān, ${ }^{7}$ the hero and some of the narratives soon made it into Islam and its periodization models have continuously been used as time-structuring devices. ${ }^{8}$ Just as Christian interpreters had found Christ predicted in the book of Daniel, so Muslim interpreters found in the same texts a prediction of Muhammad. ${ }^{9}$ For example, Ibn Hazm (d. 1064 CE) argued that the small stone that pulverized all previous kingdoms was a reference to Muhammad..$^{10}$ In the

I.e., The Apocalypse of John the Little. See Penn, When Christians First Met Muslims, 146-55.

6 Yefet ben 'Elī, A Commentary on the Book of Daniel by Yephet Ibn Ali the Karaite, ed. and trans. D. S. Margoliouth (Oxford: Clarendon Press, 1889), 12-14 [Arabic N.B. 27-31]; Saadiah Gaon, The Book of Daniel: The Commentary of R. Saadia Gaon: Edition and Translation, ed. and trans. J. Alobaidi (Bern: Lang, 2005), 446-56. For Ibn Ezra and other Jewish interpreters of the four kingdom schema under Muslim rule, see Breed, "History of Reception," 93-95. The incorporation of the Muslim empire into the schema is traceable to earlier tracts, such as Pirqe Rabbi Eliezer 28 and the eighth-century liturgical poet Pinhas the Priest (Breed, "History of Reception," 93-94).

7 Cf. the parallels identified in Gabriel S. Reynolds, The Qur'ān and the Bible: Text and Commentary (New Haven: Yale University Press, 2018), passim.

8 See for instance Lorenzo DiTommaso, Book of Daniel and the Apocryphal Daniel Literature, SVTP 20 (Leiden: Brill, 2005), 171-79; and Breed, "History of Reception," 251-52.

9 On Muslim readings of the Bible, see Martin Accad, "Muhammad's Advent as the Final Criterion for the Authenticity of the Judeo-Christian Tradition: Ibn Qayyim al-Jawziyya's Hidāyat al-ḥayārā fì ajwibat al-yahüd wa-'Inașārā," in The Three Rings: Textual Studies in the Historical Trialogue of Judaism, Christianity and Islam, ed. B. Roggema, M. Poorthuis, and P. Valkenberg (Leuven: Peeters, 2005), 217-36.

10 See Ibn Hazm (d. 1064 CE) in Camilla Adang, Muslim Writers on Judaism and the Hebrew Bible: From Ibn Rabban to Ibn Hazm, IPTS 22 (Leiden: Brill, 1996), 16o-61. 
eighteenth century, the Shi'ah Muslim Ismācil Qazvīnī identified the fourth kingdom as Rome and the pre-Islamic Arab kingdoms and the kingdom "that shall never be destroyed" (Dan 2:44) as the Islamic empire. ${ }^{11}$

The examples above represent only scattered glimpses into the rich and variated reception of Daniel and Danielic motifs under Muslim rule. Through converts, polemics, and candid inquiry, literary motifs and philosophical ideas easily traversed confessional borders and were adapted to fit new worldviews. Since much of the literary heritage of Christian Arabic-speakers remains largely uncharted, a treasury of inter-religious interaction and conceptual redesign is yet to be unveiled. No early Christian Arabic commentary on Daniel has come down to us. Thus, in the present chapter, we will mainly focus on three selected chronological interpretations as reflected in translations of Daniel composed by and for Christian Arabic-speakers in pre-modern times: firstly, the identification of the four kingdoms in Daniel 7; secondly, the associations of these kingdoms with historical empires in the addition of a fourteenth vision incorporated into the canonical version of Daniel; and thirdly, the interpretation of the "seventy weeks of years" in Dan 9:24-27.

The brief glance offered in these three examples indicates how readily history was re-written in the intertwined processes of conceptualizing history and making biblical narratives relevant to new socio-historical settings. Though the four kingdom schema has been used extensively throughout the ages to periodize history, many Bible commentators in late antique and mediaeval times also spent a disproportional amount of attention on these four verses in Dan 9:24-27. This passage, which concerns the coming of the messiah and the seal of prophecy, assumes a prominent position in the sources of the present study as well. Thus, though the interpretations of "the seventy weeks of years" do not deepen our understanding of the kingdom motif as such, it does offer us further insights into the importance of sacred history in the multi-religious environment of the Near East. Both Jews and Christians engaged in historical speculation based on the biblical narratives, yet the chronology in the Septuagint sometimes deviates from that in the Masoretic text (cf. the genealogical lists in Genesis 5 and 11). Although this discovery was not new, the deviations became painfully evident as these different versions began to circulate in the same language, Arabic, and were consulted by Muslims, who by the ninth century believed that the Qurān offered a rival version (or

11 Dennis Halft, "Ismāc̄il Qazvīnī: A Twelfth/Eighteenth-Century Jewish Convert to Imāmī Šì' ism and His Critique of Ibn Ezra's Commentary on the Four Kingdoms (Daniel 2:31-45)," in Senses of Scripture, Treasures of Tradition: The Bible in Arabic among Jews, Christians and Muslims, ed. M. L. Hjälm, BibAr 5 (Leiden: Brill, 2017), 28o-304, here 290. 
interpretation) of the narratives in the Jewish and Christian scriptures. When pertinent, therefore, we will also make reference to Judeo-Arabic commentaries as well as an early Christian Arabic historiography and thereby let the larger context shed light on the Arabic translations under our scope.

By the ninth century, substantial parts of the Bible had been rendered into Arabic by Christians in the Near East. ${ }^{12}$ The early production focused in particular on making the biblical books used in Christian liturgy available to an Arabic-speaking audience. As a consequence, there is a notable overrepresentation of the Gospels, Pauline Epistles, and the Psalms. ${ }^{13}$ Prior to the invention of the printing press and Western missionary activities in the sixteenth century, when complete Bibles in Arabic began to be produced, the disproportionate production of these three kinds of texts remained unaltered. ${ }^{14}$ It is surprising, therefore, that Arabic translations of Daniel, which did not feature significantly in the Byzantine liturgy, are so prominent in the textual record of the first centuries of Christian Arabic literature. ${ }^{15}$ From the ninth to the fourteenth centuries, at least five different versions of Daniel appeared. ${ }^{16}$

12 Although primarily spurred by the general linguistic transition to Arabic among Near Eastern Christians, I agree with Sidney H. Griffith's suggestion that the impetus behind Arabic Bible translations was also the collection of the Qurān in the middle of the seventh century, as a means to "set the biblical record straight in Arabic," The Bible in Arabic: The Scriptures of the "People of the Book," in the Language of Islam (Princeton: Princeton University Press, 2013), 53. The earliest extant witnesses date to the ninth century and their original compositions can be traced back to the last part of the eighth century with some confidence. Any earlier date of origin is speculative, Miriam L. Hjälm, "Arabic Palaeography," in Textual History of the Bible, ed. A. Lange and Emanuel Tov, BrillOnline ed. (Leiden: Brill, forthcoming), ch. 4.1.3.2.11. A longer version is available in Miriam L. Hjälm, "A Paleographical Study of Early Christian Arabic Manuscripts," Collectanea Christiana Orientalia 17 (2020): 37-77.

13 Hjälm, "Arabic Palaeography." See there an update of early manuscripts and relevant bibliography vis-à-vis the standard work on Christian Arabic literature: Georg Graf, Geschichte der christlichen arabischen Literatur, 5 vols (Città del Vaticano: Biblioteca Apostolica Vaticana, 1944-1953), vol. 1 .

14 For recent overviews, see Miriam L. Hjälm, "Arabic Texts," in Textual History of the Bible, ed. F. Feder and M. Henze, BrillOnline ed. (Leiden: Brill, forthcoming), ch. 1.2.12; Ronny Vollandt, Arabic Versions of the Pentateuch: A Comparative Study of Jewish, Christian, and Muslim Sources (Leiden: Brill, 2015).

15 Miriam L. Hjälm, Christian Arabic Versions of Daniel: A Comparative Study of Early MSS and Translation Techniques in MSS Sinai Ar. 1 and 2, BibAr 4 (Leiden: Brill, 2016).

16 Hjälm, Christian Arabic Versions, 43-45. 
Early witnesses to these versions, which we will discuss in more detail below, are found in the following manuscripts: ${ }^{17}$

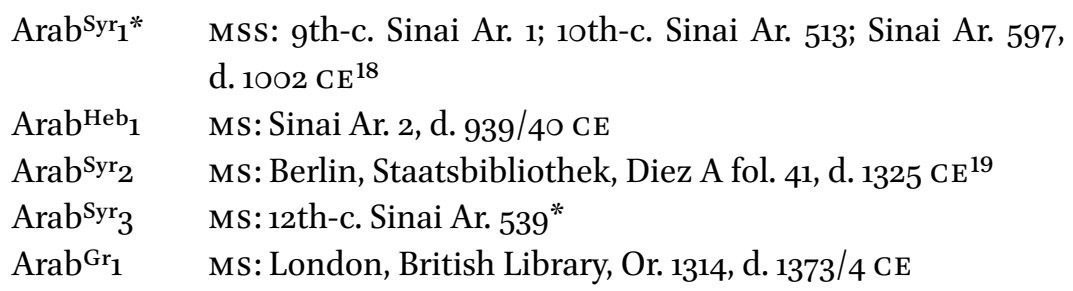

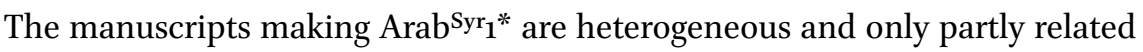
to one another. ${ }^{20}$

Arabic translators often struggled with — or took advantage of - the wealth of biblical Vorlagen, especially in Greek and Syriac, available to them. As a result, interpretations in Arabic texts do not necessarily fall into the expected ecclesial corrals and these Daniel translations are no exception. In many patristic commentaries in Greek and Latin, the four kingdoms in Daniel 7 are equated with those in Daniel 2, which were usually thought to be the historical kingdoms of Babylonia, Medio-Persia, Greece, and Rome. The third kingdom, which in the vision of Daniel 7 is depicted as a leopard, is identified as Greece and its four wings typically represent the four kings that inherited Alexander

17 According to Löfgren, another tenth- or eleventh-century witness from ArabSyri* is attested in Oxford, Bodleian Libraries, Fraser (Or.) 257. See Oscar Löfgren, Studien zu den arabischen Danielübersetzungen mit besonderer Berücksichtigung der christlichen Texte nebst einem Beitrag zur Kritik des Peschitatextes (Uppsala: Lundequitska bokhandeln, 1936), 54. The classification above (e.g., Arab ${ }^{\mathrm{Syr}_{2}}$ ) indicates the primary Vorlage (in superscript) followed by version in chronological order. An asterisk indicates that text witnesses are only loosely related in the group or that a specific manuscript exhibits notable variations in relation to other witnesses in the same group. In addition to these groups, the tenth-century Sinai Ar. NF Parchment 18 contains a version of Daniel but the leaves are glued together and cannot be identified.

18 Hjälm, Christian Arabic Versions; for an earlier date for Sinai Ar. 597, see Alexander Treiger, "From Theodore Abū Qurra to Abed Azrié: The Arabic Bible in Context," in Senses of Scripture, Treasures of Tradition: The Bible in Arabic among Jews, Christians and Muslims, ed. M. L. Hjälm, BibAr 5 (Leiden: Brill, 2017), 11-57, 42.

19 The last six chapters are missing in the earliest witness to this family, Sinai Ar. NF Paper 9 (ca. tenth-eleventh centuries) and large parts are missing in the thirteenth-century manuscript Sinai Ar. 9, including Daniel 7. Hjälm, Christian Arabic Versions, 36-38; 65-66.

For their interrelations, see Hjälm, Christian Arabic Versions, 56-62. 
the Great's kingdom. By this logic, the fourth animal with ten horns is Rome and the eleventh horn is the Antichrist, who is yet to come. However, in the Syriac tradition (cf. Ephrem the Syrian, d. 373 CE and many Peshitta manuscripts) the kingdoms are more often identified as Babylonia, Media, Persia, and Greece. ${ }^{21}$ Thus, from that perspective the Antichrist had already come and was identified as Antiochus Epiphanes IV (d. 164 BCE), the persecutor of the Jews and defiler of the temple. A similar interpretation was advocated by the Neoplatonic philosopher Porphyry (d. 305 CE), but rejected by Jerome (d. $420 \mathrm{CE}$ ) on the grounds that he believed that Antichrist was yet to appear and would only do so when Rome had fallen into the hands of ten kings. For Jerome, Porphyry's interpretation further needed to be opposed since it questioned the predictive character of the passages: Porphyry argued that the author of Daniel lived during the time of Antiochus and "did not foretell the future so much as he related the past." 22

Because the same Arabic Bible translations and biblical Vorlagen often circulated in various Christian communities, it may be difficult to identify the ecclesial identity of the texts. Although most Arabic translations of Daniel in

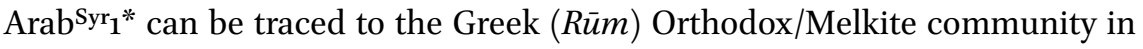
Palestine on paleographical grounds, the Syriac Vorlagen they consulted left traces and sometimes resulted in interpretations that would have seemed foreign or even objectionable to the community a few centuries earlier. In its description of the kingdom schema in Daniel 7, Sinai Ar. 1 (fols. 21a-22a) includes the interpretive additions that are inserted and marked as rubrics in many manuscripts of the Peshitta, and thus identifies the lion as the kingdom of the Babylonians (Dan 7:3-4), the bear as the kingdom of the Medians (Dan 7:4-5), the leopard as the kingdom of the Persians (7:5-6), and the fourth animal as the kingdom of the Greeks (Dan 7:6-7). ${ }^{23}$ The small horn is marked as Antiochus (7:8). In Sinai Ar. 513 (fols. 333b-336b), these references appear as well. While in Sinai Ar. 513, these historical identifications are syntactically

21 Some Jews and some Syriac Christians read the Maccabees into the vision, see Breed, "History of Reception," 243-44.

22 St. Jerome, Jerome's Commentary on Daniel, trans. Gleason L. Archer (Eugene, OR: Wipf and Stock, 2009), 15. As long as the reader believed that Daniel received his prophecies during Babylonian and Persian times, there was no need to question the prophetic nature of Daniel's vision. It is in this light that we should understand the Syriac tradition.

23 For the interpretive additions added in the Peshitta, see Anthony Gelston, ed., The Old Testament in Syriac according to the Peshitta Version: Part III. Fasc. 4, DodekaprophetonDaniel-Bel-Draco (Leiden: Brill, 1980), iv; 27-30; van Peursen, "Daniel's Four Kingdoms in the Syriac Tradition," 195-99. Unlike the Syriac additions which are in the form of rubrics preceding the appearance of the animals, the Arabic reference in Sinai Ar. 1 seems to point backward; probably due to a scribal mistake. 
more integrated into the running text, certain parts of them (typically the sequential numberings) are marked in red, apparently to indicate their rubrical nature ${ }^{24}$ In a similar manner, the words "and he is Antiochus" are incorporated into the text and marked in red. In contrast to Sinai Ar. 1, Sinai Ar. 513 adds "and that is Messiah" to the end of Dan 7:14 (which is not in the received Syriac text) in reference to "the son of man" who comes with the clouds of heaven. In the next manuscript, Sinai Ar. 597 (fols. 19a-21a), three of the four beasts $^{25}$ as well as Antiochus and the messiah are also identified with these historical kingdoms and figures, yet these passages are moved into the margins of the manuscript and are thus clearly set apart from the running text. The copyist must have been aware of the fact that these inclusions were not part of his community's preferred Vorlage ${ }^{26}$ yet did not oppose the Syriac flavored interpretation he found in it. In the margin of the same manuscript (fol. 2ob), the horn which springs up and displaces three of the ten horns and persecutes the saints in Dan 7:20-21 is identified as the Antichrist: al-qarn al-șaghir huwa al-Masịh al-dajjäl ("the little horn is the Antichrist"), where the Syriac renders "Antiochus." Given the identification of the Antichrist with Antiochus in Dan 7:8, "Antichrist" is probably a reference to Antiochus here too rather than referring to the Antichrist who is to come at the end of times. Yet perhaps this sudden change of vocabulary reflects the memory of what used to be the standard interpretation of the kingdom schema within the Byzantine communities, where the last kingdom is Rome and the eleventh horn the Antichrist who is yet to come. Thus, it appears that Antiochus, besides being the historical referent of the biblical text, also becomes a type of the Antichrist in the end of days and anticipates his coming rather than replacing him.

Just as in our previous three witnesses, the earliest manuscript of the next Syriac-based version, Arab ${ }^{\mathrm{Syr}}$, also contain the same historical interpretations

24 Not only the original rubrics but also running text units are sometimes marked in red, such as "then I saw a throne be placed and the Ancient of Days sat down" (Dan 7:9) seemingly in order to draw attention to them. The first kingdom is introduced as "that is, the kingdom of Babylon is the first one since it is [similar to a lion]," the second merely as "and the second is the Median kingdom," the third as "and the third is the Persian kingdom," and the fourth as "and the fourth is [that of] the Greeks."

25 The identification of the second animal/kingdom is missing.

26 Presumably, it was written in Greek, as there are some Grecisms in the rendition. For instance, Greek nominative endings are sometimes added to originally Syriac terms, see Hjälm, Christian Arabic Versions, 85. On a different note, the Arabic transcription of 'Az['] $\bar{l} l$ here should rather be read Ghabrì [']el, i.e., a transcription of the Syriac text (yet $\mathrm{G}>\mathrm{Gh}$ ) which seems to have been chosen rather than the expected Islamic adaptation of the name, i.e., Jibrïl. Cf. fol. $32 \mathrm{~b}$ in the manuscript. 
marked in red or added in the margins. ${ }^{27}$ Although its provenance is uncertain, this version was later revised and used among the Copts and probably also by the Rum Orthodox communities, who thus adopted these historical interpretations as well. ${ }^{28}$ The earliest extant sample of the third Syriac-based version, $\mathrm{Arab}^{\mathrm{Syr}} 3$, likewise contains the historical interpretations, in this case marked by an asterisk. ${ }^{29}$

In pre-Islamic patristic times, the identification of the fourth kingdom with the Greek empire and the Antichrist with Antiochus IV appear to be largely restricted to Syriac or even profane interpreters (e.g., Porphyry) and not even all Syriac authors appear to agree. Aphrahat's (d. ca. $345 \mathrm{CE}$ ) interpretations resemble those of the West and as noted above, the final kingdom was interpreted as an amalgam of the Greek, Roman, and Byzantine empires in the Syriac Apocalypse of Pseudo-Methodius and elsewhere as the Muslim kingdom. In addition, both Saadiah and Yefet sided with the Greek and Latin tradition in that they identified the third kingdom with the Greek empire. Thus, in view of this evidence, we may conclude that what used to be a minority view in pre-Islamic times had become the dominant interpretation of the four kingdoms in the Rüm Orthodox communities of the ninth to twelfth centuries and around this time also among the Copts, at least in Arabic Daniel translations. As suggested above, this change of historical perspective was in all likelihood facilitated by the widespread availability of various Vorlagen and Arabic translations to different Christian groups. Yet, the reason these Christian Arabic translators and copyists, regardless of confessional tradition, chose the Syriac pattern of interpretation might not simply be a consequence of common access to the same corpus of texts. In Islamic times, this interpretation conveniently moved focus away from the relation between the Roman/Byzantine empires and Islam and the latter's place within the schema. Perhaps this motivated scribes to preserve the historical interpretations in these three widespread Arabic versions even when copyists were aware that they were not part of the community's primary biblical Vorlage.

27 I.e., MS Berlin, Staatsbibliothek, Diez A fol. 41. dated 1325 CE (fols. $247 \mathrm{~b}-248 \mathrm{~b}$ ).

28 Löfgren, Studien, 9-14. This version exhibits characteristics similar to the translation of Jeremiah ascribed to a certain Pethion, perhaps of East Syriac origin. It is often argued that this translator is the same Pethion as that mentioned in the tenth-century Fihrist of Ibn Nadīm. The identification is nevertheless questionable (Miriam L. Hjälm, "The Major Prophets in Arabic: The Authorship of Pethiōn Revisited in Light of New Finding," in Senses of Scripture, Treasures of Tradition: The Bible in Arabic among Jews, Christians and Muslims, ed. M. L. Hjälm [Leiden: Brill, 2017], 448-83). See also Alin Suciu, "Textual History of Jeremiah's Prophecy to Pashur," in Textual History of the Bible, ed. F. Feder and M. Henze, BrillOnline ed. (Leiden: Brill, forthcoming), ch. 2.5.1.

For more on this version, see Löfgren, Studien, 49-54. 
Be that as it may, as we have already seen in the introduction to this chapter, the flexibility of the kingdom motif motivated communities in the Near East to adapt the model in several directions and the same denominations interpreted the fourth kingdom in a variety of ways. In various genres, the Islamic empire was increasingly incorporated into the schema and a number of apocalyptic texts reflecting Danielic motifs appeared. Our next example, however, took one step further and added to the biblical text itself.

\section{The Fourteenth Vision of Daniel: The Kingdom Motif Expanded}

In one recension of the only Greek-based version of Daniel, $\mathrm{Arab}^{\mathrm{Gr}}$ 1a, the Danielic corpus is expanded with an additional narrative, known as the Fourteenth Vision of Daniel. ${ }^{30}$ This apocalyptic text, which was transmitted in both Coptic and Arabic, has recently received a great deal of attention and there is no need to recapitulate all the fruits of these studies here. ${ }^{31}$ Suffice it to say, according to Jos van Lent, the original version of the Fourteenth Vision appears to be lost yet historical references in the extant manuscripts allow us to date it to the early Abbasid era, possibly around $760 \mathrm{CE} .{ }^{32}$ Other scholars, including Lorenzo DiTommaso, point out that the version of the Fourteenth Vision available to us today might have been composed around the eleventh century or later. ${ }^{33}$ It appears that the original version was in Coptic or possibly Greek and the Arabic version is, therefore, a translation. ${ }^{34}$ As Samuel Rubenson has shown, the Copts began to use Arabic around the tenth and eleventh centuries and that by the fourteenth century, it had become their preferred literary language. ${ }^{35}$ The earliest extant Arabic witness to the Fourteenth

$30 \quad$ Hjälm, Christian Arabic Versions, $53-54$.

31 An edition of the Arabic text with a German translation is available in Carl H. Becker, "Das Reich der Ismaeliten im koptischen Danielbuch," Nachrichten von der königlichen Gesellschaft der Wissenschaften zu Göttingen, philologisch-historische Klasse (1916): 7-57. For a more extensive bibliography, see DiTommaso, Book of Daniel, $45^{6-58}$ and Jos van Lent, "The Proto-Fourteenth Vision of Daniel," in Christian-Muslim Relations: A Bibliographical History, vol. 1: 600-90o, ed. D. Thomas and B. Roggema (Leiden: Brill, 2009), 1:309-13. There an edition and English translation is promised in Jos van Lent, "Coptic apocalyptic writings from the Islam period" (PhD diss., Leiden University) listed as forthcoming.

32 van Lent, "The Proto-Fourteenth Vision of Daniel."

33 See the discussion in DiTommaso, Book of Daniel, 179-84.

34 DiTommaso, Book of Daniel, 180.

35 Samuel Rubenson, "The Transition from Coptic to Arabic," EMA 27-28 (1996): 77-91; and idem, "Translating the Tradition. Aspects on the Arabization of the Patristic Heritage in Medieval Egypt," ME 2 (1996): 4-14. 
Vision, MS London, British Library, Or. 1314 (fols. 240a-251b), is dated to this time: $1373 / 4$ CE. ${ }^{36}$ The translation of the canonical parts of Daniel $\mathrm{Arab}^{\mathrm{Gr}} 1$ is attributed to a certain al-Alam al-Iskandarí. ${ }^{37}$ Oscar Löfgren worked out the stemmatic relationship between the manuscripts of $\mathrm{Arab}^{\mathrm{Gr}}{ }_{1}$, and suggested that the Fourteenth Vision was appended to this Arabic version of Daniel when the canonical version was revised according to a Coptic Vorlage (cf. fol. 252a), which he claims took place before $1350 \mathrm{CE} .{ }^{38}$ However, as the earliest witness to $\mathrm{Arab}^{\mathrm{Gr}}{ }_{1}$ is the London manuscript, we cannot entirely rule out that the apocalypse was originally not a part of the translation or its early reception and later removed from what became the standard recension of $\mathrm{Arab}^{\mathrm{Gr}} 1 .{ }^{39}$

It is well known that the apocalyptic genre was popular among Near Eastern Christians, and Daniel served as a source of inspiration for a range of Daniel legenda ${ }^{40}$ The juxtaposition of biblical and non-biblical texts is also common, at least in the early manuscripts. ${ }^{41}$ What is extraordinary with the Fourteenth Vision is not the composition itself but that it was sporadically incorporated into the biblical corpus where it was marked as the last of fourteen chapters. In the London manuscript, it follows Bel and the Dragon.

In imitation of Dan 10:1, the apocalypse commences with the words "In the third year of Kyros the Persian, who became king over Babylon, was a word made known to Daniel whose name is Baltashassar, and the word is true." Daniel then informs us in the first person that he fasted from meat and wine and did not use oil for twenty-one days and that he received the vision while standing at the river al-Dijla (i.e., the Tigris), which is a repetition of Dan 10:24. The narrative is then copied almost word for word from Dan 7:2-8 and repeats the narrative of the four animals and eleven horns that emerged from the fourth horrifying animal. In the Fourteenth Vision, Daniel sees another eight

36 For additional manuscripts, see van Lent, "The Proto-Fourteenth Vision of Daniel," 1:311; cf. $n .38$ below.

37 For a summary of previous research and new findings regarding this version of the canonical Daniel, see Hjälm, Christian Arabic Versions, 23-32.

38 For a stemmatic relationship of the manuscripts (not all of them include the Fourteenth Vision), see Löfgren, Studien, 27; reproduced in Hjälm, Christian Arabic Versions, 32.

39 It is generally assumed that al-'Alam was active in or around the tenth century, as we are told that the translator used an old Greek majuscule text as his Vorlage. This information was perhaps added to give the translation authority. In general, old biblical texts may have been available long after they were composed or ceased to be used. The juxtaposition of biblical and non-biblical books was quite common in the early stage of Arabic Bible production (ninth-tenth century), which suggests to me an early rather than a late provenance.

$40 \quad$ See DiTommaso, Book of Daniel.

41 Hjälm, "Arabic Texts." 
emerging after the first eleven so that all together, nineteen horns grew out of the animal. Daniel sees an angel and falls, frightened, to the ground but is raised up and the vision is explained to him (cf. Dan. 8:15-19a). The first animal, a lioness, ${ }^{42}$ represents Persia, a kingdom which will dominate the world for five hundred and fifty-five years. The second animal symbolizes Rome (al-Rüm), which will march against Ethiopia (al-Habasha) and rule the earth for eight hundred and eleven years. The third empire is that of al-Alānniyunna (i.e., the Hellenistic world), which will rule for one thousand years and thirty days. The fourth kingdom represents the sons of Ismael, and nineteen Muslim kings will rule until the end of the world. The description of the Islamic kings that follows is related to a number of historical events depicted in an obscure and oblique way reminiscent of the style of Daniel 11. Some scholars have identified the seventeenth king as Marwān II (r. 744-50 CE), the last Umayyad Caliph, and the eighteenth king subsequently as al-Saffāh (r. $\left.75^{\mathrm{O}}-54 \mathrm{CE}\right)$, the first 'Abbasid caliph. ${ }^{43}$ The nineteenth, presumably fictional, king is born of a Muslim father and a Roman/Byzantine mother (al-Rüm). According to the vision, this evil king is eventually attacked by a foreign people called "the Turks." After a war so fierce that the water of the river became undrinkable due to all the blood that ran into it, he falls into their hands in the Egyptian city of Ashmūn. The Romans/Byzantines seize control over Egypt but soon the people of Gog and Magog arise and with them the Antichrist (didd al-Masīh) who kills Enoch ${ }^{44}$ and Elijah. Partly reminiscent of Daniel 7, the "Ancient of Days," who looks like a "son of man," finally appears on the clouds of heaven. He raises up Enoch and Elijah from the dead and defeats the Antichrist. Echoing the end of Daniel 8, Daniel is then told to seal up the vision "because this is the end of all things."

The juxtaposition of the canonical chapters of Daniel and this new composition was likely motivated by their thematic parallels. As remarkable as it may seem today, the inclusion of the Fourteenth Vision among the canonical chapters thus follows the same logic that motivated the incorporation of the Additions in Daniel 3, and the additions of Bel and the Dragon and the story of Susanna to this biblical book centuries before. The fact that the twelve protocanonical chapters of Daniel appear to be a collection of stories and visions from different sources virtually invite such additions.

42 Arabic labwa, cf. the Septuagint which understands the Hebrew hä' in 'aryēh as a feminine marker.

43 van Lent, "The Proto-Fourteenth Vision of Daniel," 1:310.

44 The manuscript is defective, but Enoch is named in the Coptic version (DiTommaso, Book of Daniel, 181). 
Around the twelfth century, attention paid to the historical sense and literary structure of the Bible seemingly caused yet another alteration in this elastic composition. In $\mathrm{Arab}^{\mathrm{Syr}} 3$, the story of Susanna, in which Daniel is portrayed as a young man, is integrated into Daniel 1 and placed between Dan 1:2 and 1:3, that is right after the reader is told that the Jews are brought into Babylonian captivity and before Daniel and his friends are summoned to the king's court.45

The examples offered so far indicate that the Arabic-speaking Coptic communities were exceptionally liberal both in terms of their view of canonicity and Vorlage adherence. The latter is true at least also for Rüm Orthodox communities in the Palestinian area. The multitude of available Vorlagen in many Eastern Christian communities offered a treasure store of exegetical possibilities. However, in other contexts this richness caused problems. In stark contrast to the above examples, the richness of traditions led to an unprecedented focus on the literal level of scripture in our final case study.

The second earliest Christian Arabic version of Daniel, $\mathrm{Arab}^{\mathrm{Heb}}{ }_{1}$, is represented by one manuscript alone, Sinai Ar. 2 (dated 939/4O CE). Curiously enough, this rendition is primarily based on a Hebrew Vorlage, but exhibits a certain influence from other Vorlagen. ${ }^{46}$ As expected given its Hebrew Vorlage, it does not contain the historical interpretations in Daniel 7 but there is one abnormality that calls for attention: parts of the passages in Dan 9:24-27, i.e., "Daniel's seventy weeks of years," are rendered twice, in two Arabic versions which vary only slightly in content, suggesting that the reception of this passage was particularly important ${ }^{47}$ Indeed, this passage was prized by Christian commentators in late antiquity because it seemed to contain detailed predictions of the coming of the messiah. In the more elaborative $\mathrm{Arab}^{\mathrm{Syr}_{2}}$, represented in this study by the Berlin manuscript (fol. 251b), the Christian interpretation is

45 For a more exhaustive account, see M. L. Hjälm, "The Christian Arabic Book of Daniel: Extant Versions, Canonical Constellations, and Relation to the Liturgical Practice, with an Appendix of 'The Song of the Three Young Men," cco 12 (2015): 115-78.

46 Hjälm, Christian Arabic Versions, 92-103. Note that in Dan 9:26, Sinai Ar. 2 reads "king" instead of "prince," which points to a dependence on the Peshitta, although the sensitive character of the passage and the fact that it has been revised, makes this passage difficult to assess. In Dan 9:25, there are a few deviations between the Masoretic text, the Peshitta, and Theodotion. In all these cases, Sinai Ar. 2 follows the Hebrew as expected.

47 Fols. 26ob-261a; cf. Hjälm, Christian Arabic Versions, 101-103. In Ms London, BL, Or. 1314 fols. 222b-223a, the last verse is repeated with slightly different words. 
advocated by subtle, interpretative additions. For instance, the narrative in Dan 9:24 in the original text is propelled by a range of infinitives. In the Arabic text, the introduction of the verb yașir ("to become") causes the last infinitive $m$-s- $h$ ("to anoint") to be rendered as the noun "anointed," i.e., "the Messiah" (cf. Syr.). ${ }^{48}$ Thus, "to anoint the holy of holies" is transformed into "and the holy of holies becomes the Messiah," i.e., the messiah becomes/replaces the temple. In Dan 9:27 the original text "he shall cause the sacrifice and the offering to cease" is explicated and rendered "and the sacrifices of the Jews and their offerings will cease." ${ }^{\text {99 }}$

Patristic interpreters shared the conviction that the passage pointed towards Jesus Christ yet they did not agree on the exact interpretation implied by the seventy weeks, which immediately became a matter of inner-Christian discussion (dates are provided according to modern historical calculation in brackets below). In his discussion of the passage, Jerome simply repeated the interpretations of previous commentaries on the passage rather than providing his own. ${ }^{50}$ For instance, he records the interpretation of Julius Africanus (d. ca. $24 \mathrm{OCE}$ ), for whom the seventy weeks represent four hundred and seventy-five solar years (which is the equivalent of four hundred and ninety Hebrew lunar years), beginning with the twentieth year of Artaxerxes, King of the Persians (r. 464-423 BCE) when the petition regarding the restoration of Jerusalem was issued (cf. Nehemiah 2) and ending with the time of Jesus Christ. ${ }^{51}$ According to Jerome, Eusebius (d. ca. $340 \mathrm{CE}$ ) gives two alternative interpretations of the seventy weeks. In the first, four hundred and eighty-three years (i.e., seven + sixty-two weeks) elapse between the first year of Cyrus the Persian (са. 56о вСЕ) and the end of the reign of a king named as Alexander (probably Alexander Jannaeus, d. 76 в СЕ). The first seven weeks represent the time it took to build the temple (cf. John 2:20). According to the second interpretation, the period begins in the sixth year of Darius, which is the same year as the temple was completed (i.e., 516 вСЕ), and the seven plus the sixty-two weeks, (together four hundred and eighty-three years) ends the year in which

48 This interpretation is offered in the Peshitta, which renders the passive participle mšịna here rather than a verbal noun. The Syriac text is also behind the constant reference to "anointed" as "the anointed," since in Syriac the distinction between the definite and indefinite state is not clearly upheld.

49 In a marginal note for Dan 9:25, where we read "the going forth of the word to restore and to build Jerusalem," an alternative for the Arabic word kalām, "word, speech," is provided: kalima, "word." This is also a common translation of $\lambda$ óros, i.e., the Christ, who is specifically referred to in the comment following the gloss. Thus, it is Christ who restores and builds (the heavenly?) Jerusalem.

50 St. Jerome, Commentary on Daniel, 95.

$5^{1}$ St. Jerome, Commentary on Daniel, 95-98. 
Herod killed the high priest Hyrcanus, which Eusebius reckons as the end of the Maccabaean line. In this interpretation, Christ who was thought to have replaced the Maccabean line both as king and high priest is crucified in the middle of the last week. ${ }^{52}$ Jerome notes that this last week is sometimes extended to seventy years as a way of including events subsequent to the passion of Christ yet he himself is skeptical about this expansion and is, in general, cautious with interpretations that move the fulfillment of the prophecy beyond the time of Christ. ${ }^{53}$

In relation to the Jews, the essential question related to whether Jesus Christ was the messiah. Theodoret of Cyrus (d. ca. $457 \mathrm{CE}$ ) accused the Jews of placing Daniel among the historical books to avoid the subject all together. ${ }^{54}$ The East Syriac exegete Isho'dad of Merv (fl. ca. 850 CE) brings up a similar subject. ${ }^{55}$ Yet in his commentary on Dan 9:24-27, Saadiah discusses the chronology at length and enters into polemical dispute with Christians. According to Saadiah, the first seven weeks represent forty-nine years, commencing with the destruction of the First Temple (i.e., $587 \mathrm{BCE}$ ) and ending when Cyrus gave the Jews permission to return (i.e., $539 \mathrm{BCE}$ ) to Jerusalem. The following sixtytwo weeks equal four hundred and thirty-four years and refer to the duration of the Second Temple. The end of the sixty-two weeks marks the end of the Jewish monarchy, both the Davidic and Aaronic lines (i.e., the Maccabees), which he interprets as the meaning of the words "the anointed one was cut off." The "leader who will come with destruction" is identified as Titus, who destroyed the temple (7O CE) ${ }^{56}$ Pursuing a familiar polemical device of his, Saadiah indicates that Christian exegesis is deficient because it is based on a poor command of the Hebrew language, suggesting that in the clause "The anointed will be cut off (Dan 9:26) ['the anointed'] does not designate

52 St. Jerome, Commentary on Daniel, 98-103; cf. Eusebius, Church History, trans. A. C. McGiffert; From Nicene and Post-Nicene Fathers; Second Series, vol. 1, ed. by P. Schaff and H. Wace (Buffalo: Christian Literature Publishing Co., 189o), revised and edited for New Advent by Kevin Knight, http://www.newadvent.org/fathers/25o1.htm, Book I, ch. 6, §9.

53 St. Jerome, Commentary on Daniel, 103-104. Theodoret counted backwards from the time Jesus began his mission to the time when Nehemiah was granted permission to rebuild Jerusalem (Theodoret of Cyrus, Commentary on Daniel, trans. Robert C. Hill [Atlanta: Society of Biblical Literature, 2006], 245-47).

54 Beatrice, "Pagans and Christians on the Book of Daniel," 32. The prophecies in Daniel were nevertheless discussed in talmudic literature, cf. Breed, "History of Reception," 311.

55 Cf. Ceslas van den Eynde, ed., Commentaire d'Išo'dad de Merv sur l'Ancien Testament: V. Jérémie, Ézéchiel, Daniel, csco 328, ss 146 (Leuven: Peeters, 1972), 102.

56 Saadiah Gaon, The Book of Daniel, 599-6o5. For more on Saadiah's Daniel commentary, see Eliezer Schlossberg, "The Character and Exegetical Goal of the Commentary of Rav Saadia Gaon to the Book of Daniel," PAAJR $5^{6}$ (1990): 5-15 (Hebrew). 
one anointed, but all the anointed," an expression common in the Hebrew language, which in this case means simply that the practice of anointing leaders will no longer be maintained. ${ }^{57}$ Undoubtedly, this explanation was directed against the Christian interpretation of this passage which understood "the anointed will be cut off" to refer to the death of Christ, the anointed. Saadiah then continues: 58

And when they saw that their master was born one hundred [and] thirty five years before the destruction of the second Temple, they considered that these four hundred [and] thirty four ${ }^{59}$ years started at the time [the vision] was told to Daniel. Therefore they added the fifty years earlier to that to the one hundred [and] thirty five years [and placed them] after the birth of their master.

On first reading, it is difficult to understand what Christian interpretation Saadiah is referring to. The timespans in the Christian interpretations we have looked at above are different from those he describes. However, his rationale becomes clearer if we surmise that he was reacting to the chronology put forward by Tertullian (d. $240 \mathrm{CE}$ ) in Adversus Judaeos. Firstly, Tertullian began calculating the "sixty two weeks plus half a week" from the moment Daniel received his vision, i.e., in the first year of Darius's reign (539 BCE). Thus, it is this date that Saadiah is referring to when he says "they considered that these four hundred and thirty four years started at the time [the vision] was told to Daniel." Secondly, Tertullian places the "seven weeks and half a week,"

57 Saadiah Gaon, The Book of Daniel, 6o2. See also Miriam L. Hjälm, "Universal Wisdom in Defense of the Particular: Medieval Jewish and Christian Usage of Biblical Wisdom in Arabic Bible Treatises," in Wisdom on the Move: Late Antique Traditions in Multicultural Conversation: Essays in Honor of Samuel Rubenson, ed. Susan Ashbrook Harvey, Thomas Arentzen, Henrik Rydell Johnsén and Andreas Westergren, Vigiliae Christianae Supplements 161 (Leiden: Brill, 2020), 224-46.

58 Saadiah Gaon, The Book of Daniel, 6o3.

59 Saadiah Gaon, The Book of Daniel, 6o3. Chazan reads 490 (Robert Chazan, "Daniel 9:2427: Exegesis and Polemics," in Contra Iudaeos: Ancient and Medieval Polemics between Christians and Jews, ed. O. Limor and G. G. Stroumsa, TSMEMJ 10 [Tübingen: Mohr Siebeck, 1996], 143-59, here 150). It does not matter for the overall calculation. Whether or not they assigned importance to the distinction of the seven and the sixty-two weeks, most Christian commentators start counting these weeks at a date around the reconstruction of the Second Temple, unlike Saadiah, who begins counting before that event. Several commentators place the last week of the vision after the coming of Christ and different commentators assign different length of historical time to this week. Yet few commentators interpret the entire seven week period as the historical time after the coming of the messiah. 
i.e., fifty-two years (which starts with the advent of Christ and concludes with Vespasian's destruction of Jerusalem), at the end of the prophecy. ${ }^{60}$ Again, it seems likely that it was this relocation of the fifty-two years to the end of the prophecy which inspired Saadiah's comment that "they added the fifty years earlier to that to the one hundred [and] thirty five years [and placed them] after the birth of their master." ${ }^{\prime 1}$ His other figure, the "one hundred and thirty five years," seems to be the product of Saadiah's own rather idiosyncratic calculation based on his belief that the Persian kingdom lasted for only thirty-four years (Yefet counts the length of the Persian kingdom as fifty-seven years). ${ }^{62}$ Thus, Saadiah claims that Christians added in total almost two hundred years to the chronology of Daniel in order to support their Christological doctrine. He continues: "And unsatisfied with that, they attacked us pretending that we deducted from the count two hundred years, out of prejudice against their master." 63

Next, Saadiah tries to establish a parallel between the Christian calculations of Daniel 9 and their chronological calculations based on the book of Genesis: 64

They did the same concerning the date of the creation. In fact, they learned by hearing that the messiah comes in the fifth thousands of the creation. Yet, when the $[y]$ counted and found that their master had come in the fourth thousands [of the creation], they added one thousand years to the chronology in order that [the coming of their messiah] coincides with the fifth thousands.

6o St. Jerome, Commentary on Daniel, 106-107; cf. Tertullian. "An Answer to the Jews," in The Ante-Nicene Fathers: Translations of the Writings of the Fathers down to A.D. 325. Volume 3: Latin Christianity: Its Founder, Tertullian, ed. A. Roberts and J. Donaldson, trans. Sydney Thelwall, rev. A. Cleveland Coxe (Eerdmans: Grand Rapids), 3:283-324, here 298.

61 Ishodad of Merv starts counting the seventy weeks from the time the Jews begin the construction of the temple. The first seven weeks symbolize the time it took to build the temple minus three years as Christ is told that the temple took forty-six years to construct (cf. John 2:20). The sixty-two weeks represent the time elapsing from the time the temple and the city were restored until the crucifixion of Jesus Christ. From the crucifixion to the attack by the Romans and the introduction of the image into the temple by Pilate (!), one week of years plus three years elapsed. See van den Eynde, Commentaire, 118-21.

62 Chazan, "Daniel 9:24-27," 150; Yefet ben 'Elī, A Commentary on the Book of Daniel, 49. In general, Yefet's calculations match those of Saadiah's, but Yefet does not include any references to Christians (A Commentary on the Book of Daniel, 49-51).

63 Saadiah Gaon, The Book of Daniel, 6o3.

64 Saadiah Gaon, The Book of Daniel, 6o3. 
Continuing the parallel, Saadiah then notes that Christians accuse Jews of having tampered with the Hebrew version of the Bible in order to hide predictions of the Christian messiah, and that they claim to have found a copy of the Bible which adds a thousand years to the chronology between "Adam and the Flood." ${ }^{5}$ The Septuagint chronology of the time between the creation and the flood is indeed longer than that in the Masoretic text. Already in the third century, some Christians accused Jews of having tampered with the scriptures and Eusebius includes a detailed description of the differences between the Samaritan, Greek, and Hebrew versions of the chronology up to the flood. ${ }^{66}$ Yet, according to Yonatan Moss, the first time chronological discrepancies in Genesis are explicitly connected to Christological considerations and Jewish-Christian polemics is in the Genesis commentary by the Syriac Orthodox polymath Jacob of Edessa (d. $708 \mathrm{CE}$ ). ${ }^{67}$ This connection between chronology in Genesis and polemics in Daniel appears again in the chronography by the Rüm Orthodox bishop Agapius of Manbij who died the same year as Saadiah (941/2 CE). Agapius explains that the "seven weeks and the sixty two weeks" are the four hundred and eighty-three years between the end of the construction of Jerusalem during the reign of the Persian king Artaxerxes Longhand and the advent/death of Christ at the time of Herod (nothing is made of the last week). But for Agapius there was more at stake in the interpretation of this chronology of Dan 9:24-27 than simply Jewish-Christian arguments about the identity of the messiah. In a way conspicuously similar to Saadiah, he connects the interpretation of this passage with the correct reception of the biblical narratives. In Agapius's text, emperor Constantine asks for the reason behind the difference between the Jewish and Christian Bibles (i.e., the Septuagint) and is led to the conclusion that Jews had altered their scriptures to hide the coming of the messiah. ${ }^{68}$

65 Saadiah Gaon, The Book of Daniel, 604.

66 Josef Karst, Eusebius Werke: Die Chronik, gcs 20 (Leipzig: J. C. Hinrichs'sche Buchhandlung, 1911), 34-41. See an extensive account in Yonatan Moss, "Versions and Perversions of Genesis: Jacob of Edessa, Saadia Gaon, and the Falsification of Biblical History," in Jews and Syriac Christians: Intersections across the First Millennium., ed. Aaron M. Butts and Simcha Gross (Tübingen: Mohr Siebeck, 2020), 207-29.

67 Moss, "Versions and Perversions."

68 Alexandre Vasiliev, ed. and trans., Kitab al-'unvan. Histoire universelle écrite par Agapius (Mahboub) de Menbidj: Vol. I.1, PO 5 (Paris: Firmin-Didot, 1910), 645-6o. See also a partial translation in John C. Lamoreaux, "Agapius of Manbij," in The Orthodox Church in the Arab World (700-1700): An Anthology of Sources, ed. S. Noble and A. Treiger (DeKalb: Northern Illinois University Press, 2014), 136-59. For a recent discussion of the Septuagint narrative in Agapius's account, see Maria Conterno, "Found in Translation: Agapius, the 
It is not so much the topic of distortion as the fact that it is argued in connection to Dan 9:24-27 which attracts attention to the similarities between Saadiah's commentary and Agapius's chronography. The differences between the chronologies in the Septuagint and the Masoretic text are not reflected in Daniel and it might seem as an unlikely step to connect an actual textual corruption in Genesis with a matter of interpretation in Daniel. ${ }^{69}$ Nevertheless, there is a clear parallel here since already some of the earliest Christian interpreters found a relationship between the six days of creation and the six thousand years between the creation (the "first Adam") and the coming of the messiah (the "last Adam," i.e., Christ), as established in the Septuagint's chronology of Genesis. ${ }^{70}$

Based on the interpretation of the "seventy weeks," it is clear that Saadiah did not read Agapius's text but had access to a different work. ${ }^{71}$ Furthermore, Moss has pointed out that Saadiah wrote his treatise before Agapius composed his, but most importantly, that he was puzzled over what biblical text Christians resorted to: Christians accused Jews of having tampered with the chronology yet the copy Saadiah apparently advised exhibited the same chronology as that in the Hebrew text. Had he read Agapius's commentary, he would have understood that the Christian version of the Bible he accessed was based on the Syriac Peshitta, which Agapius rejected precisely because of its chronological dissimilarity with the Septuagint. In this passage, Agapius is trying to prevent

Septuagint, and the 'Falsified' Torah of the Jews," in Intercultural Exchange in Late Antique Historiography, ed. M. Conterno and M. Mazzola, вв (Leuven: Peeters, forthcoming).

69 The minor textual differences between the Greek and the Hebrew versions (cf. Breed, "History of Reception," 314-15) are hardly intended here, although, in turn, they sometimes affected Christian commentaries.

70 The use of the Danielic chronology for a similar purpose can be seen as early as Hippolytus's (d. 235 CE) commentary on Daniel (Moss, "Versions and Perversions;" Treiger, "From Theodore Abū Qurra," 21-26). Origen interpreted the seventy years as the four thousand and nine hundred years which had elapsed from Adam to the end of the first century (Breed, "History of Reception," 315).

71 Moss argues that the Christian source we have discussed above originally came from a West Syriac community. In addition to the identification of Jacob's text, the argument rests on the assumption that the Western Syrians, more than any other Christian community, were characterized by their allegiance to both the Septuagint and the Peshitta. As noted above, Rūm Orthodox communities also used both biblical versions. In either case, as pointed out by Moss, the charge of distortion was used by other Christian communities by the tenth century ("Versions and Perversions"). Explicit preference was given to the Septuagint in several Christian communities (Treiger, "From Theodore Abū Qurra," 21-26). 
Christians from using the Peshitta, which he knows is primarily based on the Hebrew text and, therefore, in his view, displays the erroneous chronology: ${ }^{72}$

Now the mutilated Torah and all the books of the Prophets in Syriac copies which are in the hands of the Christians, are widespread in all the countries of the earth of the East and West, so that because of that the Christians cannot explain them and give an account of this question. All the scholars and the learned and those who wanted to translate the books of the Prophets from one language to another, or to make an exegesis of what they contained, changed nothing and commented on the Syriac text, which is in disagreement with the translation of the Seventy because the Jews mutilated it and changed it after the Resurrection of the Messiah.

It appears that the differences between various versions of the Bible were increasingly known in the long ninth century and apparently used mainly by Christians to argue that the Jews deliberately misinterpreted or altered their scriptures. ${ }^{73}$ Although Jewish and Christian scholars fought one another to establish the validity of their own tradition's scriptural authenticity (at least in the example above), these discrepancies were much more problematic for Christians due to their use of multiple Vorlagen. In addition, Jewish and Christian leaders could hardly have been ignorant of the fact that by this time the Qur'ān was perceived by Muslims as transmitting an alternative version of the biblical narratives. Although the Qur'ān apparently relies on previous Scriptures for the credibility of its own message, the idea that Jews and Christians distorted the original version of the Bible increasingly spread among Muslims. ${ }^{74}$ The Muslim notion of biblical distortion sprung from actual

72 Vasiliev, Kitab al-'unvan, 659-6o. Vasiliev's translation is provided here and can be found online: http://www.tertullian.org/fathers/agapius_history_o1_partı.htm.

73 Moss, "Versions and Perversions." See there also additional Syriac sources relating to the topic. A link between the translation of the Septuagint and Jewish denial of the Christian messiah is found also in Eutychius/Sa'id b. al-Bațiq (d. 940 CE), see Abraham Wasserstein and David J. Wasserstein, The Legend of the Septuagint: From Classical Antiquity to Today (Cambridge: Cambridge University Press, 2006), 141-44. Variation between the Syriac and the Greek Bibles is further discussed in the introduction to an Arabic translation of the Syrohexapla by a certain al-Hārith, widely assumed to have been active in the tenth century.

74 For a select few works on the topic, see Gabriel S. Reynolds, "On the Qur'anic Accusation of Scriptural Falsification (tahrif) and Christian Anti-Jewish Polemic," JAOS 130 (2010): 189-202; and Adang, Muslim Writers; David Thomas, ed., The Bible in Arab Christianity, CMR 6 (Leiden: Brill, 2006). 
and assumed deviations between the Qur'ann on the one hand and the Bible on the other. However, the knowledge of the textual discrepancy displayed in the Septuagint and the Hebrew Bible eventually spread to Muslim intellectuals, probably from debates similar to the one above and due to greater familiarity with the Bible among Muslims because of the increasing production of Arabic Bible translations. The Muslim scholar al-Bīrūnì (d. ca. $1048 \mathrm{CE}$ ) was well aware of both Jewish and Christian interpretations of Dan 9:24-27, which he dismisses. Just as in the cases above, the interpretation of this passage appears in connection to a report on the deviations between the Hebrew Bible and the Septuagint. According to al-Bīrūnī, the Hebrew Bible is "comparatively free from confusion" whereas the Septuagint is garbled to a greater extent. Al-Bīrūnìs passage serves as a good example of how Muslims on the one hand relied on biblical narratives wherein they found Muhammad predicted, and on the other hand suspected Jews and in particular Christians for scriptural distortion. ${ }^{75}$

\section{Concluding Remarks}

Based on Christian Arabic translations of Daniel, three examples have been offered of how chronological motifs in the Bible were understood and used in Near Eastern communities subsequent to the rise of Islam.

The first example centered on the identification of the four kingdoms in Daniel 7. It was demonstrated that the association of the fourth kingdom with Greece and the Antichrist with Antiochus IV, which was a minority view in patristic times, became the dominant interpretation in three out of five premodern Arabic versions of Daniel. The reason for this might be traced to their use of Syriac Vorlagen. Yet, Arabic copyists in the monasteries of Palestine and Egypt where many of these texts were produced often worked with a multitude of Vorlagen and different Arabic versions. Thus, we cannot exclude the possibility that they deliberately adopted the Syriac model to avoid discussing the relation between Islam and the Roman/Byzantine empire, which had previously been identified as the final kingdom. Whatever their motivation, these widely disseminated Arabic Bible translations transmitted the view that the vision was already fulfilled, an interpretation previously held largely by Syrians and, in the West, connected with Porphyry and secularism.

75 al-Bīrūnī, The Chronology of Ancient Nations, trans. Edward C. Sachau (London: William H. Allen, 1879), esp. 16-27. 
If the first example represents an active attempt to avoid discussing the role played by the Islamic empire in sacred history or simply reflects dependence on a specific Vorlage, the second example demonstrates a different way of attempting to solve the problem. The incorporation of a rather late, apocalyptic narrative into the canonical composition of Daniel, was a deliberate attempt to face the reality of the Muslim presence and try to make sense of it as part of sacred history. Perhaps such texts were produced also to entertain their readers or to offer hope of redemption. ${ }^{76}$ As both this and the previous versions circulated in the same Christian communities, it is clear that a plurality of interpretations were allowed or even valued within these communities.

The third example focused on the renditions of "the seventy weeks of years" in Daniel 9:24-27. Subtle alterations and irregularities in some Arabic renditions signaled the importance of this passage and motivated a deeper, comparative study. In the commentary by Saadiah Gaon and the chronography of his contemporary Agapius of Manbij, the interpretation of the seventy weeks not only reflected the vitality of contemporary discussions about the identity of the messiah but also raised the issue of the transmission of the biblical text. Although accusations of distortion of messianic material formed part of early Jewish-Christian polemics, the changed intellectual and social context of Jewish and Christian communities under Islam gave the debate about biblical chronology a new relevance.

Though much material remains to be explored, the examples above demonstrate how biblical texts were used in the continuous process of relating historical events to sacred history as revealed in biblical prophecy and how those interpretations could be changed according to the needs of each age. They show how sacred texts possess a relevance that transcends historical time, or perhaps rather that sacred texts are sacred when a community of believers chooses to use the language and symbolism in them to interpret their contemporary, historical reality, not only at one point in history but constantly, so that the texts become a constant in an ever changing world.

\section{Bibliography}

Accad, Martin. "Muhammad's Advent as the Final Criterion for the Authenticity of the Judeo-Christian Tradition: Ibn Qayyim al-Jawziyya's Hidāyat al-ḥayāāa fĩ ajwibat al-yahūd wa-'Inașārā." Pages 217-36 in The Three Rings: Textual Studies in the

76 van Lent, "The Proto-Fourteenth Vision of Daniel." 
Historical Trialogue of Judaism, Christianity and Islam. Edited by B. Roggema, M. Poorthuis, and P. Valkenberg. Leuven: Peeters, 2005.

Adang, Camilla. Muslim Writers on Judaism and the Hebrew Bible: From Ibn Rabban to Ibn Hazm. IP TS 22. Leiden: Brill, 1996.

Beatrice, Pier Franco. "Pagans and Christians on the Book of Daniel." StPatr 25 (1991): 27-45.

Becker, Carl H. "Das Reich der Ismaeliten im koptischen Danielbuch." Nachrichten von der königlichen Gesellschaft der Wissenschaften zu Göttingen, philologisch-historische Klasse (1916): 7-57.

Bīrūnī, al-. The Chronology of Ancient Nations. Translated by Edward C. Sachau. London: William H. Allen, 1879 .

Breed, Brennan W. "History of Reception." Pages 85-97, 243-52, 309-20 in Daniel: A Commentary, by Carol A. Newsom with Brennan W. Breed. otL. Louisville: Westminster John Knox, 2014.

Chazan, Robert. "Daniel 9:24-27: Exegesis and Polemics." Pages 143-59 in Contra Iudaeos: Ancient and Medieval Polemics between Christians and Jews. Edited by O. Limor and G. G. Stroumsa. тsmemJ 10. Tübingen: Mohr Siebeck, 1996.

Conterno, Maria. "Found in Translation: Agapius, the Septuagint, and the 'Falsified' Torah of the Jews," in Intercultural Exchange in Late Antique Historiography. Edited by M. Conterno and M. Mazzola. вв. Leuven: Peeters, forthcoming.

DiTommaso, Lorenzo. The Book of Daniel and the Apocryphal Daniel Literature. SVTP 20. Leiden: Brill, 2005 .

Eusebius. Church History. Translated by A. C. McGiffert. From Nicene and Post-Nicene Fathers. Second Series, Vol. 1. Edited by P. Schaff and H. Wace. Buffalo: Christian Literature Publishing Co., 189 o.

Eynde, Ceslas van den, ed. Commentaire d'Išo'dad de Merv sur l'Ancien Testament: V.Jérémie, Ézéchiel, Daniel. csco 328. ss 146. Leuven: Peeters, 1972.

Gelston, Anthony, ed. The Old Testament in Syriac according to the Peshitta Version: Part III. Fasc. 4, Dodekapropheton-Daniel-Bel-Draco. Leiden: Brill, 1980.

Graf, Georg. Geschichte der christlichen arabischen Literatur. 5 vols. Città del Vaticano: Biblioteca Apostolica Vaticana, 1944-1953.

Greisiger, Lutz. "The Apocalypse of Pseudo-Methodius [Syriac]." Pages 163-71 in Christian-Muslim Relations: A Bibliographical History, vol. 1: 60o-9oo. Edited by D. Thomas and B. Roggema. Leiden: Brill, 2009.

Griffith, Sidney H. The Bible in Arabic: The Scriptures of the "People of the Book" in the Language of Islam. Princeton: Princeton University Press, 2013.

Halft, Dennis. "Ismā̄ìl Qazvīnī: A Twelfth/Eighteenth-Century Jewish Convert to Imāmī Šìism and His Critique of Ibn Ezra's Commentary on the Four Kingdoms (Daniel 2:31-45)." Pages 280-304 in Senses of Scripture, Treasures of Tradition: The Bible in Arabic among Jews, Christians and Muslims. Edited by M. L. Hjälm. BibAr 5 . Leiden: Brill, 2017. 
Hjälm, Miriam L. "The Christian Arabic Book of Daniel: Extant Versions, Canonical Constellations, and Relation to the Liturgical Practice, with an Appendix of "The Song of the Three Young Men."' cco 12 (2015): 115-78.

Hjälm, Miriam L. Christian Arabic Versions of Daniel: A Comparative Study of Early MSS and Translation Techniques in MSS Sinai Ar. 1 and 2. BibAr 4. Leiden: Brill, 2016.

Hjälm, Miriam L. "The Major Prophets in Arabic: The Authorship of Pethiōn Revisited in Light of New Findings." Pages 448-83 in Senses of Scripture, Treasures of Tradition: The Bible in Arabic among Jews, Christians and Muslims. Edited by M. L. Hjälm. BibAr 5. Leiden: Brill, 2017.

Hjälm, Miriam L. "A Paleographical Study of Early Christian Arabic Manuscripts." Collectanea Christiana Orientalia 17 (2020): 37-77.

Hjälm, Miriam. "Universal Wisdom in Defense of the Particular: Medieval Jewish and Christian Usage of Biblical Wisdom in Arabic Bible Treatises." Pages 224-46 in Wisdom on the Move: Late Antique Traditions in Multicultural Conversation: Essays in Honor of Samuel Rubenson. Edited by Susan Ashbrook Harvey, Thomas Arentzen, Henrik Rydell Johnsén and Andreas Westergren. Vigiliae Christianae Supplements 161. Leiden: Brill, 2020.

Hjälm, Miriam L. "Arabic Palaeography." Ch. 4.1.3.2.11 in Textual History of the Bible. Edited by Armin Lange, et al. BrillOnline ed. Leiden: Brill, forthcoming.

Hjälm, Miriam L. "Arabic Texts." Ch. 1.2.12 in Textual History of the Bible. Edited by F. Feder and M. Henze. BrillOnline ed. Leiden: Brill, forthcoming.

St. Jerome. Jerome's Commentary on Daniel. Translated by Gleason L. Archer. Eugene, OR: Wipf \& Stock, 2009.

Karst, Josef. Eusebius Werke: Die Chronik. GCs 20. Leipzig: J. C. Hinrichs'sche Buchhandlung, 1911.

Lamoreaux, John C. "Agapius of Manbij." Pages 136-59 in The Orthodox Church in the Arab World (700-1700): An Anthology of Sources. Edited by S. Noble and A. Treiger. DeKalb: Northern Illinois University Press, 2014.

Lent, Jos van. "The Proto-Fourteenth Vision of Daniel." Pages 309-13 in Christian-Muslim Relations: A Bibliographical History, vol. 1: 600-90o. Edited by D. Thomas and B. Roggema. Leiden: Brill, 2009.

Löfgren, Oscar. Studien zu den arabischen Danielübersetzungen mit besonderer Berücksichtigung der christlichen Texte nebst einem Beitrag zur Kritik des Peschitatextes. Uppsala: Lundequitska bokhandeln, 1936.

Moss, Yonatan. "Versions and Perversions of Genesis: Jacob of Edessa, Saadia Gaon, and the Falsification of Biblical History." Pages 207-29 in Jews and Syriac Christians: Intersections across the First Millennium. Edited by Aaron M. Butts and Simcha Gross. Tübingen: Mohr Siebeck, $202 \mathrm{O}$.

Penn, Michael Philip. When Christians First Met Muslims: A Sourcebook of the Earliest Syriac Writings on Islam. Oakland: University of California Press, 2015. 
Peursen, Wido van. “Daniel's Four Kingdoms in the Syriac Tradition." Pages 189-207 in Tradition and Innovation in Biblical Interpretation: Studies Presented to Professor Eep Talstra on the Occasion of his Sixty-Fifth Birthday. Edited by W. Th. van Peursen and J. W. Dyk. ssN 57. Leiden: Brill, 2011.

Reynolds, Gabriel S. "On the Qur'anic Accusation of Scriptural Falsification (taḥrif) and Christian Anti-Jewish Polemic." JAOS 130 (2010): 189-202.

Reynolds, Gabriel S. The Qur'ān and the Bible: Text and Commentary. New Haven: Yale University Press, 2018.

Rubenson, Samuel. "The Transition from Coptic to Arabic." EMA 27-28 (1996): 77-91.

Rubenson, Samuel. "Translating the Tradition. Aspects on the Arabization of the Patristic Heritage in Medieval Egypt." ME 2 (1996): 4-14.

Saadiah Gaon. The Book of Daniel: The Commentary of R. Saadia Gaon: Edition and Translation. Edited and translated by Joseph Alobaidi. Bern: Lang, 2005.

Schlossberg, Eliezer. "The Character and Exegetical Goal of the Commentary of Rav Saadia Gaon to the Book of Daniel." PAAJR $5^{6}$ (1990): $5^{-15}$ (Hebrew).

Sucio, Alin. "Textual History of Jeremiah's Prophecy to Pashur." Ch. 2.5.1 in Textual History of the Bible. Edited by F. Feder and M. Henze. BrillOnline ed. Leiden: Brill, forthcoming.

Tertullian. "An Answer to the Jews." Pages 283-324 in The Ante-Nicene Fathers: Translations of the Writings of the Fathers down to A.D. 325. Volume 3: Latin Christianity: Its Founder, Tertullian. Edited by A. Roberts and J. Donaldson. Translated by Sydney. Revised by A. Cleveland Coxe. Eerdmans: Grand Rapids, 1993.

Theodoret of Cyrus. Commentary on Daniel. Translated with an Introduction and Notes by Robert C. Hill. Atlanta: Society of Biblical Literature, 2006.

Thomas, David, ed. The Bible in Arab Christianity. cmR 6. Leiden: Brill, 2006.

Treiger, Alexander. "From Theodore Abū Qurra to Abed Azrié: The Arabic Bible in Context." Pages 11-57 in Senses of Scripture, Treasures of Tradition: The Bible in Arabic among Jews, Christians and Muslims. Edited by M. L. Hjälm. BibAr 5. Leiden: Brill, 2017.

Vasiliev, Alexandre, ed. and trans. Kitab al-'unvan. Histoire universelle écrite par Agapius (Mahboub) de Menbidj: Vol. I.r. PO 5. Paris: Firmin-Didot, 1910.

Vollandt, Ronny. Arabic Versions of the Pentateuch: A Comparative Study of Jewish, Christian, and Muslim Sources. BibAr 3. Leiden: Brill, 2015.

Wasserstein, Abraham and David J. Wasserstein. The Legend of the Septuagint: From Classical Antiquity to Today. Cambridge: Cambridge University Press, 2006.

Yefet ben 'Elī. A Commentary on the Book of Daniel by Yephet Ibn Ali the Karaite. Edited and translated by David S. Margoliouth. Oxford: Clarendon Press, 1889. 